\title{
Periodization of the Early Postnatal Development in the Rat With Particular Attention to the Weaning Period
}

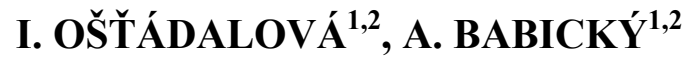

${ }^{1}$ Centre for Cardiovascular Research, Prague, Czech Republic, ${ }^{2}$ Institute of Physiology, Academy of Sciences of the Czech Republic, Prague, Czech Republic

Received May 7, 2012

Accepted May 24, 2012

\section{Summary}

The early postnatal period is characterized by a great plasticity with critical windows in which any inadequate insult or intervention may be able to influence both positively and adversely postnatal growth and development. After birth the rat littermates enter the presuckling period (initial 6 hours terminated by the first nursing), characterized by transition from the amniotic fluid to the air, by the changes of the ambient temperature, by the termination of placental nutrition and by oxidative stress. After this stage the suckling period initiates and the littermates start to consume milk of their mothers. Comsumption of milk culminates on day 15 , then decreases and terminates on postnatal day 28. The end of the suckling period and the onset of physiological weaning is determined by the moment when the youngs for the first time consume the solid food together with milk (postnatal day 17 in rats). On day 19 the first intake of drinking water occurs. The weaning period terminates by the last consumption of maternal milk - on postnatal day 28. It is necessary to stress that the duration of early postnatal periods is independent of the changes of body weight. The precise knowledge of individual ontogenetic periods critical for further development is crucial for the prediction and explanation of reactions to various pathogenetic stimuli both under experimental conditions and in clinical medicine.

\section{Key words}

Rat • Ontogenetic development • Presuckling period • Suckling period $\bullet$ Weaning period

\section{Corresponding author}

I. Ošt'ádalová, Institute of Physiology, Academy of Sciences of the Czech Republic, Vídeňská 1083, 14220 Prague 4, Czech Republic. E-mail: iostadal@biomed.cas.cz

\section{Introduction}

Infant growth during the early postnatal period is obviously the result of the development of complex functional, structural and metabolic mechanisms, which are, however, not yet entirely clarified. The organism is not fully developed at birth and the process of maturation thus continues during the immediate postnatal period (Patel and Srinivasan 2010). It is evident that this period of immaturity is characterized by a great plasticity with critical windows in which any inadequate insult or intervention may be able to influence both positively and adversely postnatal growth and development. The adaptation to the insult can develop either immediately or during the later developmental period; these effects are considered as the "late effects of early adaptations". According to this idea the tissues are most sensitive to injury during the period of intensive growth. The intervention during this critical period can modify the structure and function of this particular tissue or organ. The consequences of an intervention during the critical developmental period can appear after a period of latency, either spontaneously or induced by some other insults.

The interest in this topic increased in the late fifties of the last century. Kennedy (1957) studied the late impacts of changes in nutrition, Scott (1958, 1970) analyzed the behavior of mothers. Křeček and Palatý (1967), Křeček (1970) and Koldovský et al. (1995) introduced the concept of premature weaning. Simultaneously, Ošt’ádalová and Pařízek (1968), Ošt’ádalová et al. (1970, 1976) and Barraclough (1970) 
opened the basic question of the early and late effects of different hormones. It is surprising that the interest on "late effects of early adaptations" occurred again in the last years (Netuka et al. 2006, Vickers 2011, De Mello et al. 2012). The phenomenon of postnatal plasticity, classified as the postnatal programming, became even a part of the more general concept of the developmental origins of adult health and disease (Armitage et al. 2005, Barker 2007).

The decisive role in the postnatal development is played without doubt by maternal nutrition. Possible consequences of an inadequate alimentation before weaning, during weaning and after the weaning period became a topic of an increasing number of papers (Angel and Back 1985, Huynh et al. 2008, Patel and Srinivasan 2011, Smith and Spencer 2012). While the beginning of the suckling period is clearly defined, the end of this period, i.e. the beginning of the weaning period is not fully recognized. Similarly, the end of the weaning period as well as the period of the essential presence of mothers in the litters are not precisely determined; they vary in rats from the 21st to the 26th postnatal day (Prior and Armitage 2009, Patel and Srinivasan 2010, Connor et al. 2012). The aim of this short review is, therefore, to summarize the data available on the periodization of the nutritional status during the early postnatal period in the rat.

\section{Presuckling period}

Presuckling period (first 6 hours after birth) represents a typical example of developmentally decisive critical period. The fetus makes numerous adaptations to ensure normal development in spite of its low arterial $\mathrm{PO}_{2}$ (47 mm Hg), which corresponds to an altitude of $8000 \mathrm{~m}$ ("Mt. Everest in utero", Eastman 1954). Among these adaptations are polycythemia, leftward shift of the dissociation curve, fetal hemoglobin, a high cardiac output and low arterial blood pressure, which help to provide adequate oxygen and nutrient delivery to the developing tissues. Fetal heart operates at near maximum levels and is very sensitive to increases in afterload. The major changes in oxygen saturation can be observed within delivery. During the short period of time mammalian fetus comes from the hypoxic environment with low $\mathrm{PO}_{2}$ and low oxygen saturation (18\%) into the normal atmosphere $\left(\mathrm{PO}_{2} 160 \mathrm{~mm} \mathrm{Hg}\right)$, arterial saturation increases more than five times (from 18 to $97 \%$ ). The delivery is, furthermore, accompanied by the transition from the amniotic fluid to the air, by the marked decrease of the ambient temperature, by the termination of placental nutrition and by oxidative stress. This transition requires appropriate physiological adaptations: onset of pulmonary respiration, transition from fetal to neonatal circulation, switching-on of thermoregulation and increase of basal metabolic rate (for review see Ošt'ádal et al. 2011). Very important is the change of nutrition: transplacental supply is interrupted and mother milk nutrition is not yet fully developed (Kuma et al. 2004). The nutrient deprivation, as was presented by Kuma et al. (2004) in mouse newborns, elicits in the cells a complex series of well orchestrated steps that result in the processes of degradation and recycling known as autophagy. Autophagy is a nonstop life-sustaining repairing and renewal process that is considered as necessary for turnover of cellular components with a particular importance after birth. The authors observed massive induction of autophagy in the heart muscle, the diaphragm, the lungs and the skin - the organs that face marked postnatal adaptation at the first line. The induction of autophagy was immediate and transient, reaching maximum levels only 3 to 6 hours after birth and declining to basal levels within a day or two later (Heintz 2004, Kuma et al. 2004). These studies showed that autophagy is required to produce amino acids to provide energy shortly after birth and to maintain simultaneous development.

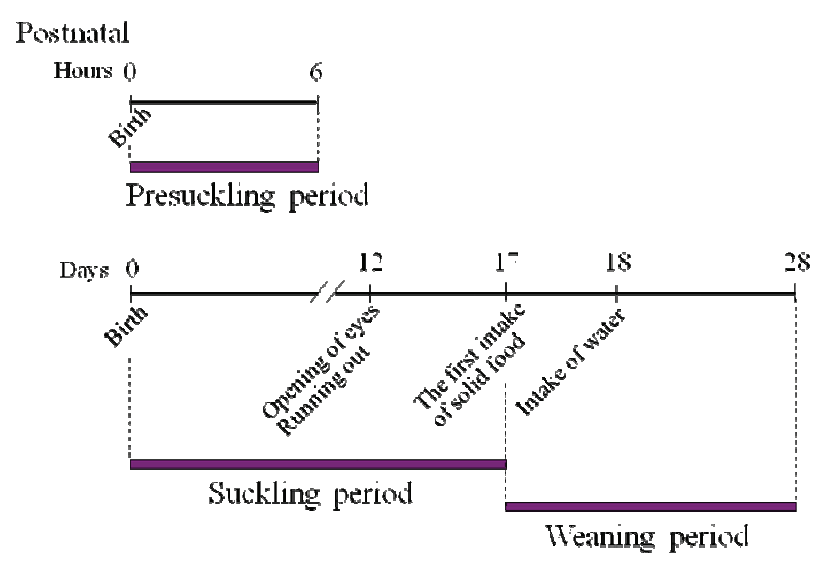

Fig. 1. Periodization of the early postnatal life in rats.

To reverse postnatal hypoglycemia, the presuckling newborns utilize glucose from glycogenolysis as well as from gluconeogenesis and plasma lactate (Mayor and Cuezva 1985). These metabolic pathways emerge after birth to reach adult values after 24 hours (Girard 1990). The utilization of 
these metabolites depends strictly on the oxygen supply. This situation is consistent with the important role of oxygen supply after birth (Fig. 1).

\section{Suckling period}

Several hours after these dramatic changes the nursing begins; the suckling period initiates (Fig. 1) and the littermates start to consume milk of their mothers. The newborns thus pass from a high carbohydrate and low fat metabolism, typical for several hours after birth, to a diet characterized by a high fat and low carbohydrate levels (Girard 1981). The composition of the maternal milk changes significantly during postnatal development: on day 10 (suckling period), the rat milk contains $72.5 \%$ of water, $12.6 \%$ of fat, $9.2 \%$ of proteins, $3.3 \%$ of carbohydrates, and $1.4 \%$ of minerals. Ten days later (weaning period) the content of fat in the milk decreases three times and the protein content two times (Godbole et al. 1981). After weaning the milk is replaced by the adult diet which contains less fat and more carbohydrates (Fereé et al. 1986).

\section{Weaning period}

It is obvious that for further analysis of the effect of nutritional status on growth and development, the exact determination of the boundary between the suckling and weaning period is of great importance. For the quantitative assessment of the duration of the exclusively maternal milk intake (suckling period) and for the limitation of the weaning period (combination of milk and solid food intake), the gamma emitters were used; the whole body measurement of radioactivity of the individual littermates was thus possible (Babický et al. 1970). The advantage of this approach is the possibility to determine the actual state of the nutritional relationships of the young, and to assess simultaneously the proportion of nutrients received by means of or independently of the maternal organism.

\section{a) Duration of maternal milk consumption}

To determine the duration of the maternal milk consumption, the rat mothers were administered strontium ${ }^{85} \mathrm{Sr}$ (element homologous to calcium) in the form of $\mathrm{SrCl}_{2}$, in a subcutaneous injection and the whole body radioactivity of sucklings was estimated (Fig. 2). Simultaneously the uptake of ${ }^{85} \mathrm{Sr}$ in the tibiae of the youngs was measured to exclude a possible contamination of the animals' body surface. The experiments revealed the maximum intake of the milk between postnatal days 12 and 19. This period corresponds with the first running of the youngs out from the litter and with the opening of their eyes. The milk intake then decreases and the littermates stop drinking maternal milk between postnatal days 27 and 28 (Babický et al. 1970); this stage represents, therefore, the end of the weaning period.

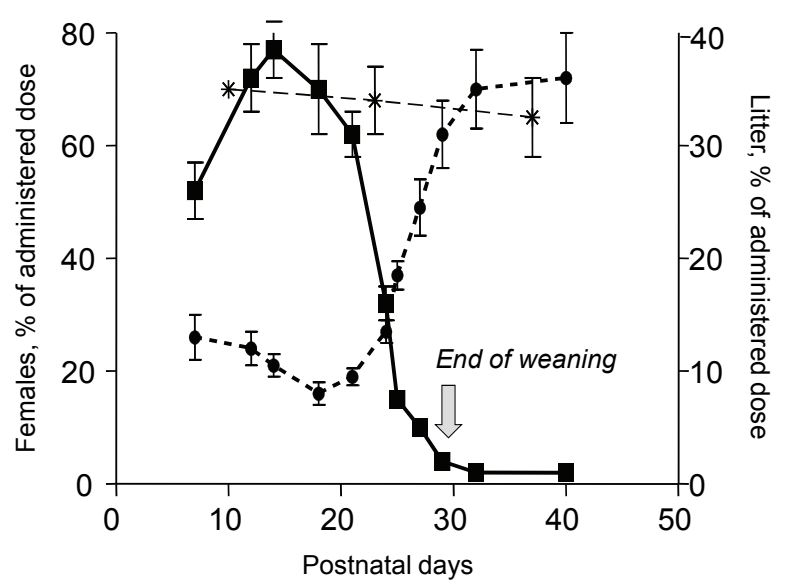

Fig. 2. Strontium ${ }^{85} \mathrm{Sr}$ metabolism during lactation (whole body and whole litter counting). Situation 24 hours after the injection. -- sucklings; ----• lactating mothers; *- -* controls (nonlactating females). Adapted from Babický et al. (1970).

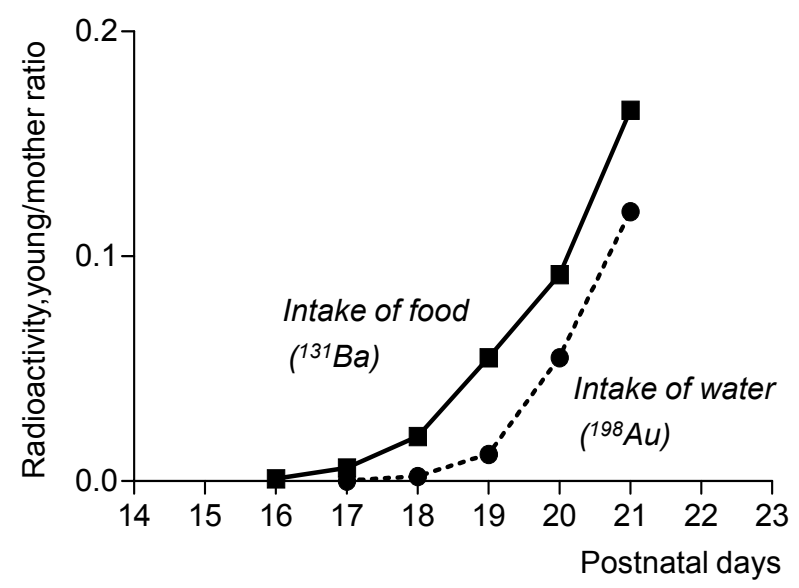

Fig. 3. Intake of ${ }^{131} \mathrm{Ba}$ labeled food (full line) and ${ }^{198} \mathrm{Au}$ labeled drinking water (broken line). Adapted from Babický et al. (1970, 1973a).

It can be summarized that the end of the suckling period and the onset of physiological weaning (Fig. 1) is determined by the moment when a young, for the first time, takes food in a form other than maternal milk. The weaning period terminates when the young animals spontaneously stop drinking maternal milk. To determine this point, the solid laboratory diet labelled the 
radionuclide barium $\left({ }^{131} \mathrm{Ba}\right)$ in the form of $\mathrm{BaSO}_{4}$ was oferred to littermates and their whole body radioactivity was measured (Fig. 3 and 5). The experiments showed that the first traces of the diet were accepted on day 17 the day of the end of suckling period and the beginning of the weaning period (Babický et al. 1973a).

Transition to solid food is probably induced by insufficient nutritional caloric supply and by higher nutritional needs of the littermates, corresponding to their advanced growth and maturity (Babický et al. 1970). It can be assumed that the possibility of taking solid food and fluids separately is associated with the development of the mechanisms of osmolarity (Křeček and Křečková 1957, Solomon et al. 1976). It seems, however, that the decisive factor is the food volume: as nutrient requirements increase, it becomes more useful to take lower volume with higher quantity of calories.

Experiments with prolonged lactation proved that the cause of the end of lactation is not on the mother's side but is connected with the higher nutritional needs of the littermates, adequate to their advanced growth and maturity (Babický et al. 1973a).

\section{b) Determination of the first intake of drinking water}

To complete the nutritional status, the analogous approach was used also for the determination of the intake of drinking water. The drinking water labeled by colloidal ${ }^{198} \mathrm{Au}$ was offered to young animals and the first traces of radioactivity were recorded on the 19th day of postnatal life (Fig. 3 and 5, Table 1). It may be assumed that the balance between the supplied calories and water in the mother's milk is disturbed by the intake of other calories from the solid food; this is probably the reason why the water intake follows the intake of solid food prandial drinking (Babický et al. 1972).

Table 1. Consumption of milk and water in developing rats.

\begin{tabular}{lcccc}
\hline $\begin{array}{l}\text { Postnatal life } \\
\text { Day }\end{array}$ & $\begin{array}{c}\text { Milk } \\
\text { ml }\end{array}$ & $\begin{array}{c}\text { Water } \\
\mathbf{m l}\end{array}$ & $\begin{array}{c}\text { Total } \\
\mathbf{m l}\end{array}$ & $\begin{array}{c}\text { Total } \\
\mathbf{m l} / \mathbf{1 0 0} \mathbf{g} \\
\mathbf{b . w} .\end{array}$ \\
\hline 15 & & & & 20.2 \\
16 & 5.9 & - & 5.9 & 19.2 \\
17 & 5.8 & - & 5.8 & 19.0 \\
18 & 5.7 & 0.2 & 5.9 & 18.5 \\
19 & 5.4 & 0.6 & 6.0 & 21.0 \\
20 & 5.4 & 2.3 & 7.3 & 21.8 \\
\hline
\end{tabular}

Adapted from Babický et al. (1972).

\section{c) Relation to body growth}

The early postnatal nutritional periods are independent of the changes in body weight, as was shown in experiments with the youngs kept in litters of different size (Kennedy 1957, Babický et al. 1973b). The boundaries of individual periods are strictly dependent on the age of the animals, and they are in good agreement with the development of osmoregulation and maturation of the higher regulatory alimentary centres (Křeček and Křečková 1957). In this relation it would be of interest to mention that at least in rats the body growth is not linear during the early postnatal period. There are two small retardations that are more expressed as decays of weight increments (Fig. 4 and 5). The decline during the first days of postnatal life is evidently connected with the dramatic changes at birth (see above) and slowly appearing maternal milk production. The slowdown of the body growth around the 16th day of postnatal life can be explained by the relatively insufficient caloric supply from the milk; this also stimulates the transition to solid food (Babický et al. 1970).

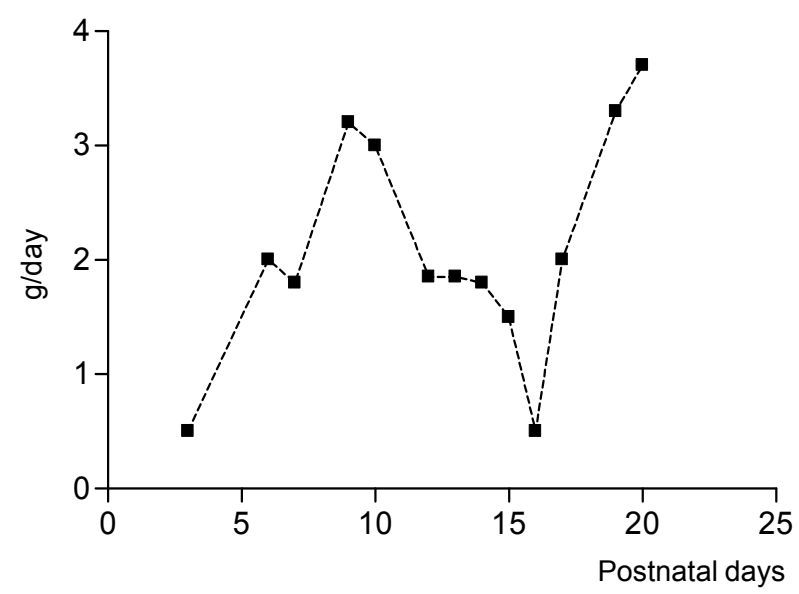

Fig. 4. The growth rate of suckling rats expressed as a daily body weight increments. Adapted from Babický et al. (1972).

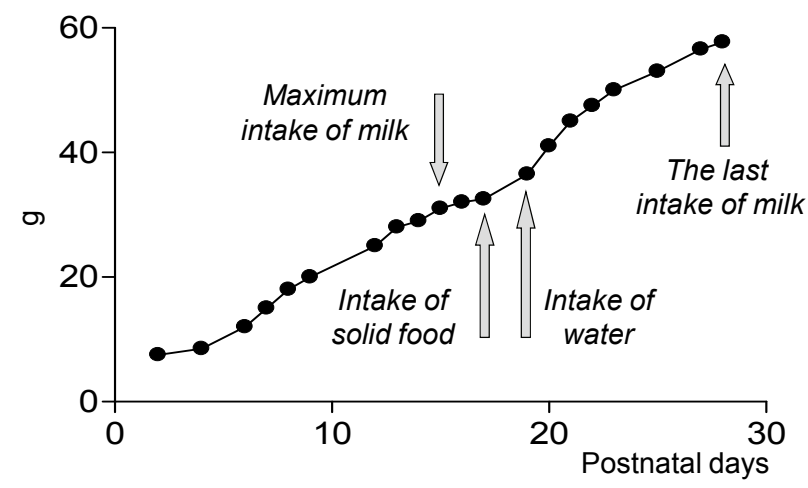

Fig. 5. Body weight of suckling rats from day 2 to day 28 . 
During the relatively long weaning period (the third and fourth weeks after birth) the youngs change stepwise the way of nutrition. While the littermates and their mothers create an absolutely integral unit during the suckling period, i.e. the youngs are in nutritional and social dependence on their mothers, during the weaning period the close interrelationship between the mother and the littermates slowly decreases. Moreover, during this period the development of the skull, teeth, and brain alimentary centres can be observed and the formation of the anatomical relationships in the oral cavity occurs (Scot 1958, Widdowson and McCance 1960). All these changes are important for adult nutritional habits.

\section{Premature weaning}

The relatively long weaning phase contrasts strikingly with sudden change from intrauterine life to the postnatal life. It should be stressed that the removal of the youngs from their mothers before the 28th day of postnatal life must be regarded as the premature weaning i.e. as an insult with all possible serious impacts on both mothers and youngs (Angel and Back 1985, Smith and Spencer 2012). For females the lactation represents a period with a very intensive metabolism accompanied with great changes in calcium handling (Fig. 2). Sudden stop of lactation induced by the premature weaning thus means a forcible interruption of the adaptation proces. These facts have direct practical implications for breeding.

\section{Conclusions}

It is worth noting that ontogenetic conclusions are often based on observations from two or three developmental stages, such as fetal, newborn and adult. However, the possible developmental changes between selected (and not exactly defined) points remain undetermined. The precise knowledge of individual ontogenetic periods critical for further development is thus crucial for the prediction and explanation of reactions to various pathogenetic stimuli, not only under experimental conditions but also in clinical medicine.

\section{Conflict of Interest}

There is no conflict of interest.

\section{Acknowledgements}

This study was supported by grant of GAČR 303/12/1162, grant of MSMT 1M0510, and grant AV0Z 50110509. The authors thank Mrs. M. Pešková for technical assistance.

\section{References}

ANGEL JF, BACK DW: Weaning and metabolic regulation in the rat. Can J Physiol Pharmacol 63: 538-545, 1985.

ARMITAGE JA, TAYLOR PD, POSTON L: Experimental models of developmental programming: consequences of exposure to an energy rich diet during development. J Physiol Lond 565: 3-8, 2005.

BABICKÝ A, OŠŤÁDALOVÁ I, PAŘÍZEK J, KOLÁŘ J, BÍBR B: Use of radioisotope techniques for determining the weaning period in experimental animals. Physiol Bohemoslov 19: 457-467, 1970.

BABICKÝ A, PAVLÍK L, PǍ̌ÍZEK J, OŠŤÁDALOVÁ I, KOLÁŘ J: Determination of the onset of spontaneous water intake in infant rats. Physiol Bohemoslov 21: 467-571, 1972.

BABICKÝ A, PǍ̌íZEK J, OŠŤÁDALOVÁ I, KOLÁŘ J: Initial solid food intake and growth of young rats of different sizes. Physiol Bohemoslov 22: 557-566, 1973 a.

BABICKÝ A, OŠŤÁDALOVÁ I, PǍ̌ÍZEK J, KOLÁŘ J, BÍBR B: Onset and duration of the physiological weaning period for infant rats reared in nests of different sizes. Physiol Bohemoslov 22: 449-456, $1973 \mathrm{~b}$.

BARKER EJ: The origins of the developmental origins theory. J Intern Med 261: 412-417, 2007.

BARRACLOUGH CA: Permanent reproductive modifications produced by exposure of neonatal animals to sex steroids. In: Postnatal Development of Phenotype. S KAZDA, VH DENENBERG (eds), Academia, Prague, 1970, pp 217-228.

CONNOR KL, VICKERS MH, BELTRAND J, MEANEY MJ, SLOBODA DM: Natute, nuture or nutrition? Impact of maternal nutrition on maternal care, offspring development and reproductive function. $J$ Physiol Lond 590: 2167-2180, 2012. 
DE MELlO WG, DE MORAIS SR, DORNELlES RC, KAGOHARA ELIAS LL, ANTUNES-RODRIQUES J, BEDRAN DE CASTRO JC: Effects of neonatal castration and androgenization on sexual dimorphism in bone, leptin and corticosterone secretion. Bone 50: 893-900, 2012.

EASTMAN NJ: Mount Everest in utero. Am J Obstet Gynecol 67: 701-711, 1954.

FEREÉ P, DECAUX JF, ISSAD T, GIRARD J: Changes in energy metabolism during the suckling and weaning period in the newborn. Reprod Nutr Dev 26: 619-631, 1986.

GIRARD J: Glucose homeostasis in the perinatal period: the critical role of pancreatic hormones and exogenous substrates in the rat. Ciba Found Symp 86: 234-250, 1981.

GIRARD J: Metabolic adaptations to change of nutrition at birth. Biol Neonate 58 (Suppl 1): 3-15, 1990.

GODBOLE VY, GRUNDLEGER ML, PASQUINE TA, THENEN SW: Composition of rat milk from day 5 to 20 of lactation and milk of lean and preobese zucker pups. J Nutr 111: 480-487, 1981.

HEINTZ N: Developmental biology: survival by self-digestion. Nature 432: 963-967, 2004.

HUYNH M, LUIKEN JJ, COUMANS W, BELL RC: Dietary fructose during the suckling period increases body weight and fatty acid uptake into skeletal muscle in adult rats. Obesity (Silver Spring) 16: 1755-1762, 2008.

KENNEDY GC: The effect of age on the somatic and visceral response to overnutrition in the rat. J Endocrinol 15: 19$25,1957$.

KOLDOVSKÝ O, HAHN P, HROMADOVÁ M, KŘEČEK J, MACHO L: Late effects of early nutritional manipulations. Physiol Res 44: 357-360, 1995.

Ǩ̌EČEK J: The weaning period as a critical period of development. In: Postnatal Development of Phenotype. S KAZDA, VH DENENBERG (eds), Academia, Prague, 1970, pp 33-44.

KŘEČEK J, KŘEČKOVÁ J: The development of the regulation of water metabolism. III. The relation between water and milk intake in infant rats. Physiol Bohemoslov 6: 26-34, 1957.

KŘEČEK J, PALATÝ V: The effect of premature weaning on the development of androgenic activity in male rats. Physiol Bohemoslov 16: 501-507, 1967.

KUMA A, HATANO M, MATSUI M, YAMAMOTO A, NAKAYA H, YOSHIMORI T, OHSUMI Y, TOKUHISA H, MIZUSHIMA N: The role of autophagy during the early neonatal starvation period. Nature 432: 1032-1036, 2004.

MAYOR F, CUEZVA JM: Hormonal and metabolic changes in the perinatal period. Biol Neonate 48: 185-186, 1985.

NETUKA I, SZARSZOI O, MALÝ J, BEŠÍK J, NECKÁŘ J, KOLÁŘ F, OŠŤÁDALOVÁ I, PIRK J, OŠŤÁDAL B: Effect of perinatal hypoxia in cardiac tolerance to acute ischaemia in adult male and female rats. Clin Exp Pharmacol Physiol 33: 714-719, 2006.

OŠŤÁDAL B, OŠŤÁDALOVÁ I, KOLÁŘ F, NETUKA I, SZÁRSZOI O: Impact of perinatal chronic hypoxia on cardiac tolerance to acute ischemia. In: Molecular Defects in Cardiovascular Disease. NS DHALLA, M NAGANO, B OŠŤÁDAL (eds), Springer, New York, 2011, pp 55-67.

OŠŤÁDALOVÁ I: The effect of single dose of oestrogens administered during the early postnatal period on the DNA content of rat bone epiphyses. Physiol Bohemoslov 25: 97-102, 1976.

OŠŤÁDALOVÁ I, PAŘÍZEK J: Delayed retardation of somatic growth of rats injected with oestrogens during the first days of postnatal life. Physiol Bohemoslov 17: 217-228, 1968.

OŠŤÁDALOVÁ I, BABICKÝ A, LOJDA Z, KOLÁŘ J, DEYL Z, PAŘÍZEK J: Some delayed effects of the administration of steroids to the newborn rats. In: Postnatal Development of Phenotype. S KAZDA, VH DENENBERG (eds), Academia, Prague, 1970, pp 267-283.

PATEL MS, SRINIVASAN M: Metabolic progamming due to alterations in nutrition in the immediate postnatal period. J Nutr 140: 658-661, 2010.

PRIOR LJ, ARMITAGE JA: Neonatal overfeeding leads to developmental programming of adult obesity: you are what you ate. J Physiol Lond 587: 2419, 2009.

SCOTT JP: Critical periods in the development of social behaviour in puppies. Psychosomatic medicine 20: 42-54, 1958.

SCOTT JP: Critical periods for the development of social behaviour in dogs. In: Postnatal Development of Phenotype. S KAZDA, VH DENENBERG (eds), Academia, Prague, 1970, pp 21-32. 
SMITH JT, SPENCER SJ: Pre-weaning over- and under-feeding alters onset of puberty in the rat without affecting kisspeptin. Biol Reprod 86: 145, 2012.

SOLOMON S, WISE P, RATNER A: Postnatal changes of water and electrolytes of rat tissues. Proc Soc Exp Biol Med 153: 359-362, 1976.

VICKERS MH: Developmental programming of the metabolic syndrome - critical windows for intervention. World $J$ Diabetes 15: 137-148, 2011.

WIDDOWSON EM, MCCANCE RA: Some effects of accelerating growth. I. General somatic development. Proc Royal Soc Lond 152: 188-206, 1960. 